International Journal of Linguistics, Literature and Culture
Available online at https://sloap.org/journals/index.php/ijllc/
Vol. 6, No. 4, July 2020, pages: 6-15
$\begin{aligned} & \text { ISSN: 2455-8028 } \\ & \text { https://doi.org/10.21744/ijllc.v6n4.901 }\end{aligned}$

\title{
Raees as Macbeth-A Transcultural Adaptation
}

Sundas Shafiq ${ }^{\text {a }}$

Nadia Anwar ${ }^{b}$

Article history:

Submitted: 18 April 2020

Accepted: 09 May 2020

\section{Keywords:}

adaptation theory;

adaptation;

canonical texts;

indigenization;

transcultural;

\begin{abstract}
Literary adaptation is a process, which reproduces the pre-existent literary piece of work into a series of altering characters, settings, actions, and storylines. Adaptations of canonical texts of great authors such as Shakespeare had won the universal dignity. By using Hutcheon's adaptation theory, this research aimed to scrutinize the impact of the transcultural adaptations of Macbeth as Raees by Government College University Dramatic Club, Lahore. The reception of Shakespeare as the manifestation of the British culture involved many social, cultural, and political factors that were analyzed in this research by using Hutcheon's concept of "indigenization" (2103:150). I had collected data from source texts, scripts, articles, interviews, observations, questionnaires, and group discussions. The Government College University Dramatic Club, Lahore team made the variations in the text to make it appropriate to the native/local culture. These variations were significant in making the transcultural adaptation as a success in the native culture.
\end{abstract}

International journal of linguistics, literature and culture (C) 2020.

This is an open access article under the CC BY-NC-ND license.

Peer-review under responsibility of International Association for

Technology, Education and Language Studies (IATELS) (https://creativecommons.org/licenses/by-nc-nd/4.0/).

\section{Corresponding author:}

Sundas Shafiq,

MPhil Scholar (English Literature)

Department of English and Literary Studies Institute of Liberal Arts University of Management and Technology

C-II, Johar Town, Lahore, Pakistan.

Email address: sundasshafiq786@gmail.com

a Department of English and Literary Studies Institute of Liberal Arts University of Management and Technology C-II, Johar Town, Lahore, Pakistan

b Department of English and Literary Studies Institute of Liberal Arts University of Management and Technology C-II, Johar Town, Lahore, Pakistan 


\section{Introduction}

In 2013, Hutcheon (2013), argued that "an adaptation is an announced and extensive transposition of a particular work or works ... as a process of creation, the act of adaptation always involves both (re-)interpretation and then (re) creation". We are living in an age where adaptation is becoming a vast field. Adapted works are strewn in all disciplines of life - art, literature, architect, history, law, economics, technology, and all kinds of sciences. In contemporary media, we find multidimensional adaptations. There are video games, mobile apps, theme parks, costumes, and other domains of arts which have successfully been adapted from the folklore, old stories or fairy tales, film, literary texts or from famous characters because people always have the desire to retell, reshow and reengage with the famous lore. Hutcheon (2013), refers to J. Hillis Miller who states: "We need the same' stories over and over, then, as one of the most powerful, perhaps the most powerful, of ways to assert the basic ideology of our culture".

In the field of art and literature adaptation has its significance. In the past, the old Greek playwrights adapted the folklore of their time. Most of the time, they transposed this folklore into written texts or in the form of a play. "Adaptation into another medium becomes a means of prolonging the pleasure of the original presentation and repeating the production of a memory" (Ellis, 1982). People got pleasure from the combination of the familiar and the unfamiliar stories. Moreover, adaptation is a subtle culture exchange process, traveling between regions and cultures thus producing hybridized multicultural values. As every region and culture have their conventional structures so in this process of transposition the true essence of the text is changed to a great extent and many new convictions, values, and things are added or excluded. Hutcheon (2013), uses the term "indigenization" to refer to the hybridization of cultures. This transposition gives rise to study adaptation as an element of a transcultural phenomenon. We can say that adaptations fulfill human desires to remain attached to the prototypes but to do experimentation and variations to invent something new.

My research involved the way a transcultural adaptation transposes Shakespeare's works to a contemporary audience and how it reflects the diversities and variations required in the different social, political, religious, and cultural contexts. Fischlin \& Fortier (2000), rightly state that "as long as there have been plays by Shakespeare, there have been adaptations of those plays". The explicit aim behind his adaptation is to transpose his works to new generations by framing them into contemporary settings. Marsden (1991) notes, "each new generation attempts to redefine Shakespeare's genius in contemporary terms, projecting its desires and anxieties onto his work". In Pakistan, Government College University, Lahore has played a leading role in illuminating the transcultural significance of Shakespeare's adaptation. These adaptations are indigenized and contextualized according to Pakistani culture and linguistic realities. In 2016, the Dramatic Club of Government College University, Lahore adapted Shakespeare's play, Macbeth. The adapted play was named as Raees. The play won much acclaim from the audience and the media. Raees was adapted on the 400th-anniversary of Shakespeare. According to the director of the play, Dr. Muhammad Salman (2018), the play is an hour and fifty minutes long and is translated into Urdu to make it more pertinent for the audience because a few people of Pakistani population speak English and even fewer understand the dense language of Shakespeare. The Urdu translation helped the audience to understand and appreciate the $17^{\text {th }}$-century English blank verse in which Macbeth was originally written. It was a huge task to make Shakespeare understandable to the local Pakistani society. The adapters made many changes in the script and contextualized it according to the audience's demands. However, at the same time, they tried their best to retain the original plot to a great extent. The adapters also changed the names from English to local which helped to portray the passions, motivations, and actions of all characters following the local context.

\section{Objective}

The objective of this research is based on cross-culture comparison - changes introduced into the script of Macbeth via Pakistani cultural conventions and audience expectations. In Raees Shakespearean text is transformed and appropriated to cater to the ideological and psychological needs of the audience. Hence, this research sets out to scrutinize the impact of transcultural adaptation of Macbeth as Raees through highlighting the variations the Translator and the Director have introduced in the script to make the text indigenous.

Shafiq, S., \& Anwar, N. (2020). Raees as Macbeth-A transcultural adaptation. International Journal of Linguistics, Literature and Culture, 6(4), 6-15. https://doi.org/10.21744/ijllc.v6n4.901 


\title{
2 Literature Review
}

The adaptation of Shakespearean plays for theatre and films have a long history. The explicit aim behind his adaptation is to transpose his works to new generations by framing them into contemporary settings. The theatrical adaptation of Shakespearean texts had become routine as early as the Restoration period in England. In Subcontinent India, Shakespeare was written, translated, and staged in local languages. Shakespeare's works were adapted in two categories: first, as an experimental form of confining his works according to the local demands, and second as a deliberate form of indigenization of his plays. Shakespeare's adaptations in India are the representative of the hybrid culture of western material and Indian conventions. Many conventions and values were merged, declined, and revived through this hybridization. C. J. Sisson in his work Shakespeare in India: Popular Adaptations on the Bombay Stage states:

\begin{abstract}
There is one country in the world, to the best of my knowledge, except possibly Germany, where the plays of Shakespeare have of recent times formed the safest and surest attraction to the indiscriminate masses who attend popular theatres, where the proprietor of a theatre could count on a profit on a Shakespeare production. That country is India, and the theatres in question are a group of theatres in the city of Bombay, clustered together in the heart of a poor Indian population. (Dionne \& Kapadia, 2014)
\end{abstract}

In 1831, a theatre in Calcutta named Prasanna Kumar Tagore performed some excerpts from Shakespeare's play Julius Caesar and also performed a Sanskrit play Uttarramcharitam in English. In 1848, at another theatre named Sans Souci Theatre in Calcutta, an English man named Barry Lewis presented a theatrical performance of Othello. An English lady played the role of Desdemona and an Indian man performed as Othello. This play shocked the audience because of the blending of English and Indian actors for the very first time in the subcontinent. The performance received opposite reviews and audience response. For a week, the play did the full house. Indian newspaper Bengal Hukaru and India Gazette (19 August 1848) published different views about the performance. One appreciated the Indian actor stating that "his delivery was somewhat cramped, but under all circumstances, his pronunciation of English was for a native remarkably good" (Desmet \& Sawyer, 1999). The account appreciated the actors, their performance, and the joint venture of English and Indian actors. On the other hand, an anonymous critic disapproved the performance of the actors especially that of Othello: "his figure is inelegant, his manner undignified, his gait awkward and ungainly...he did not deliver a single sentence with any degree of feeling and was wanting in energy" (Wells \& Stanton, 2002).

Jehangir Khambatta, Edulji Khori, and C. S. Nazir founded the first modern Indian Theatre named Parsi theatre. They were all graduates of the dramatic society of Elphinstone College in Bombay. In 1860, Parsi theatre began to adapt Shakespeare plays into Urdu and Hindi. As discussed in Chapter 1, Parsi theatre helped to make Shakespeare familiar and popular among the masses in the subcontinent. Early adaptations of his plays only changed names and setting but later the playwrights reorganized or indigenized the plots, redrafted characters to make them more local and pertinent to natives and added Indian songs and dances. Parsi theatre followed a specific strategy. The strategies included songs and dances in the plays to entertain the audience, change of Blank Verse into Urdu verses and ghazals, and tragedies into happy endings, rewriting or rearrangement of the scenes of the original text, mixing or adding scenes from other Shakespearean plays, use of dazzling sets and costumes and transforming the complex plots or narratives into the simple narrative to pander to the cultural taste and values of the audience (Dionne \& Kapadia, 2014). Playwrights of the Parsi theatre pillaged Shakespeare's themes or storyline and translated Shakespeare's plays to satisfy the audience's demand. Without any fear of cultural ambiguity or influence, it hybridized the English and Indian culture. The first Urdu translated version of Shakespeare's play was Edalji Khori's Soneke Mulki Khurshed, performed in 1871. All Urdu playwrights of Parsi theatre translated Shakespeare plays or drew inspiration from his works. Agha Hashr Kashmiri earned for himself the title of 'Shakespeare-e-Hind' meaning Shakespeare of India (Dionne \& Kapadia, 2014).

In the subcontinent other than the Parsi theatre, there were many other theatre companies that adapted Shakespearean plays. For instance, King Lear was adapted as Hara-Jita (1905) by Victorian Theatrical Company and by the name Safed Khun (1906) by Parsi Theatrical Company. Similarly, Othello was adapted as Shaheed Vafa (1898) by the Empress Victoria Company and as Sher Dil by Parsi Alfred Company following the original text but changing the tragic ending with happy ending by uniting Cordelia and King Lear. The Marathi adaptation of Shakespeare's play As You Like It as Yakashagana was done in 1860, The Tempest was adapted as Sangeet Natak in 1878, Cymbeline in 1880, and The Winter's Tale in 1906. The same year in 1906, A Midsummer Night's Dream was 
adapted as a Sanskrit play in Malayalam, with generic music and dance. The play also incorporated generic conventions such as the Nandi (prayer-prologue) and Sutradhar (chorus).

No record of Shakespearean adaptations would be left without involving Indian cinema. Shakespeare Wallah (1905) is a black and white film produced by Merchant Ivory Production Company. This film balances Shakespearean texts with the cultural and cinematic conventions of the Indian film industry. This film questions the cultural position and purpose of teaching and performing Shakespeare apparently in Indian culture but disguisedly questions the position and purpose of the British Raj in the subcontinent. The film appropriated and decontextualized scenes and lines from the Shakespearean text. Shakespeare Wallah explores issues regarding colonialism and post-colonialism.

A more self-conscious and thoroughgoing kind of indigenization emerged after Partition. The first theatrical adaptation after partition was Karanth's Barnam Vana (Macbeth) in 1979. Another indigenized adaptation of Shakespeare's A Midsummer Night's Dream is Nacha theatre by Habib Tanveer (1993). This play was indigenized in north Indian traditions and used choruses like songs and dances. Furthermore, Shakespeare's adaptation of Othello as Kathakali (1996) and of Macbeth as Stage of Blood (1997) by Lokendra Arambam were adopted in India. In the context of Bollywood cinema, Maqbool and Omkara are modern appropriations of Shakespeare's plays Macbeth and Othello respectively. Omkara is a closer adaptation of Othello, which is appropriated according to the local settings and language, whereas Maqbool is an extended illusion of Macbeth which uses the basic storyline and characters of Macbeth.

\section{Theoretical Framework}

The theoretical framework used in this research is Linda Hutcheon's theory of adaptation. The origin of the word 'adaptation' locates back to the early 17th century. The 'adapt' is a Latin word which means to fit in. According to her, an adaptation is declared as a transposition of a specific work into something new and creative. An adaptation involves many factors such as demands of the audience, the interpretation of the adapter, and the context in which the adaptation is created and received.

According to Cuddy-Keane (2003), "an adaptation from one culture to another is nothing new: The Romans adopted Greek theatre, after all, but what has been called cultural globalization has increased the attention paid to such transfers in recent years". In the case of an adaptation, the reception of adaptation is as important as the making of an adaptation. Individuals from different cultures have different perceptions and experiences, so they give meaning to the world around them according to their perceptions. Since cultures are growing over time; social and political scenarios are also changing with time. An adapter must keep all these elements in mind and appropriate the story, visuals, and settings according to the contemporary needs and demands because of the audience expectations changes with the changing context.

Indigenization is a vital dimension in transcultural adaptations. Hutcheon (2013), refers to Susan Stanford Friedman who defines "indigenization" to refer to this kind of cross-cultural encounter and accommodation". For cross-cultural adaptations, the context of reception is also as important as a context of creation. Every culture has its norms and values. Adaptation across the culture gives rise to hybrid cultures. This hybridization needs to transform the story, language, and setting of the adapted work according to the norms and values of the new environment. On the other hand, the receivers also adopt new values and norms from the adapted work. They interpret the things according to their perceptions and have the sense to choose which new grounds they have to relocate themselves. Moreover, other factors that influence an adaptation across the cultures as well as in the same culture are economic, legal, religious convictions, and growing technologies. The meaning of a text can changes over time even in one cultural context.

An adapter does not only translate the text into the native language but also considers the para-lingual aspects, audiences' visions, and value system. Hutcheon quotes Patrice Pavis, according to whom, "the intercultural is the "intergestural" (Hutcheon, 2013). In cross-cultural transpositions, the ideological, religious, national, cultural, gender, racial differences create gaps that need filling by altering the storyline according to the new place and its requirements. Para lingual effects like expressions, dress, and body gestures have to align with the setting of the play in the new place. These para-linguistic effects convey cultural information that is an index of the ideologies, values, and conventions. For an adapter, sometimes it becomes very difficult to manage the cultural or social meaning in different cultures: "when stories travel -as they do when they are adapted in this way across media, time and placethey end up bringing together what Edward Said called different processes of representation and institutionalization"

Shafiq, S., \& Anwar, N. (2020). Raees as Macbeth-A transcultural adaptation. International Journal of Linguistics, Literature and Culture, 6(4), 6-15. https://doi.org/10.21744/ijllc.v6n4.901 
(Hutcheon, 2013). Such stories absorb different local theories, modes, ideas so that they transform into a wholly new and hybrid form. Adaptations give rise to hybrid culture as they add on new values and norms in new cultures.

\section{Data Collection}

This research is based on the script of Raees and the information provided by the director, producer, and performers of the play Raees. The primary text is Shakespeare's play Macbeth along with its adapted version Raees. Moreover, this research is based on interviews, email responses, and close reading of textbooks, articles, and internet resources.

\section{Analysis}

\section{Macbeth as Raees-A Transcultural Adaptation}

When stories travel across different media, temporal, and cultural dimensions, they absorb different local theories, modes, ideas so that they transform into a wholly new and hybrid form. Adaptations give rise to hybrid culture as they add new values and norms in other cultures. Hutcheon (2013), has used the term 'indigenization' to refer to the hybridization of cultures. According to Hutcheon (2013), in transcultural adaptations; there are as many ways to indigenize a story as there are ways to tell or show it again. To give a sense of the kind of range in this particular case, I divide the transformations into three dichotomous types: (1) historicizing/dehistoricizing, racializing/deracializing, and (3) embodying/disembodying.

In transcultural adaptations, the language, setting, and story of the adapted work are transformed and appropriated according to the new context. The adapted work also focuses on the shift in political scenarios so the story and settings are transformed accordingly. Moreover, in transcultural transpositions, the ideological, religious, national, cultural, gender, and racial differences create gaps that need filling by altering the storyline according to the new place and its requirements. Para-lingual effects like expressions, dress, and body gestures have to align with the setting of the play in the new place. These para-linguistic effects convey cultural information that is an index of the ideologies, values, and conventions: "Almost always, there is an accompanying shift in the political valence from the adapted text to the "transculturated adaptation" (Hutcheon, 2013). In Raees, the translator Syed Qasim Mehmood, recontextualizing the story of Macbeth, set it in Turkish culture as he had an interest in Turkish history and Muslim culture. Moreover, he found that Turkish Culture is more accustomed and acceptable to Pakistani culture. The other reason is that Macbeth is a story of a royal General and it revolves around the story of the Scottish Royals. This story encompasses royal conspiracies, tyranny, battles, etc. To synchronize the essence of the storyline of Macbeth, the translator sets the plot into a Muslim Royal setting. Furthermore, he cuts out characters, eliminating the dialogues, and excising a change in characterization of many characters such as the translator and the director present witches as comic characters and translated text in exotic details but retain the impact of the source text. He did not rewrite or add anything; instead, he 'rehistoricized' and in the process 're-ethnicized' the play (Hutcheon, 2013). Moreover, indigenizing Macbeth meant changing the racial identity of the characters.

\section{Variations in Transcultural Adaptation of Macbeth as Raees Translation-Language Transposition}

In transcultural adaptation "a change of language is involved" (Hutcheon, 2013) Nowadays, Translation encompasses vast domains which are mainly used to interpret a text in transcultural adaptations. Transculturalism promotes translations to transfer ideas, traditions, and ideologies from one language to another language. It is considered to be bounded in cultural, political, and social scenarios. It also helps different cultures and nations to enhance their mutual understanding's cultures and history. In the case of Macbeth's translation as Raees, the major change is the conversion of its language from blank verse into simple Urdu language. The translator Syed Qasim Mahmood (17 November 1928-31 March 2010) has productively assimilated and indigenized Shakespeare's play Macbeth into the Pakistani context. The translation of Raees is standardized as it is faithful to the storyline and plot and remains almost the same but distinct in social, political, and cultural representation. According to Benjamin (1968), "A good translation is transparent; it does not cover the original, does not block its light, but allows the pure language, as though reinforced by its medium, to shine upon the original all the more fully." English and Urdu both languages have their lexical constructions, grammatical patterns, and stylistics. The relationship between the lexical, 
grammatical, and syntactical patterns of both languages is very complex. The reorganization of translated words and their pragmatic interpretation is also a challenging task. Both languages have different social realities which in turn depend upon the differences in cultural values. Both languages have different propositional meanings in word-toword translation. It needs a lot of effort to replace the words used in the source text with the correct phrase, expression, and connotation in the adapted text. The meaning of a word in a source language is also context-bound associated with many aspects. It is changed or it may be more elaborated as in the case of Urdu sentences translated from the English. For instance;

Lady Macbeth: all our service,

In every point twice done and then done double,

Were poor and single business to contend

Against those honors deep and broad wherewith

Your majesty loads our house (1.6.14-18)

:Zamurd

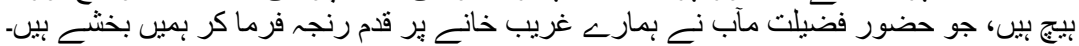
Zamurd; (Har mamlay mai aur har baat mai hamari doguni bulkay chugni khidmat in wasi aur gehray aezazat $k$ muqabalay mai heech hain, jo huzoor fazilat maab nay Hamaray gareebkhanay per qadam ranja ferma ker hamain bukhshay hain).

This occurs in every language of the world. In translation, we do not only transfer meaning from one to another language but we also transfer values, cultures, customs, thoughts, and beliefs. "An adaptation, like the work it adapts, is always framed in a context - a time and a place, a society, and a culture; it does not exist in a vacuum" (Hutcheon, 2013). In the case of a stage performance of Raees, the director Dr. Salman Bhatti also takes into account the social, temporal, and cultural differences between the time in which Macbeth was written, its translation, and the time in which it is presented to the Pakistani audience. Shakespeare's characters are not ordinary people. The language he used is not the language of common people. It must have been very challenging for the translator and the director of Raees to translate and present Shakespearean stories and characters with the same dramatic impact in Urdu language within a different cultural and political context. Through layered adaptation, the director Dr. Salman Bhatti directed these variations in such a manner as so to make the text familiar and digestible to the local audience.

Shakespeare's milieu, themes, and style are dominated by royal life, witchcraft, wars, conspiracies, and lust for power in the context of the Elizabethan era in England. All these things are not ignored in the adaptation of Raees, however, it was a difficult task to contemporize such things for the audience. The task to present Shakespeare's play in such a manner that the message can be esculent for the recipient culture and does not contradict with the language, traditions, culture, societal values, and political issues is tactfully managed in this adaptation. Raees was performed for three consecutive days. It won much acclaim from the audience and media. According to the director of the play Dr. Muhammad Salman (2018), there was a mixed audience and their collective response was that they had enjoyed the play and understood the hidden philosophy of the play in the native language. For them, this understanding was more pleasurable than watching a movie or performance in a foreign language.

On stage, each performance is live and vivid as performers and audiences experience the work in front of each other. To make this transcultural performance a genuine piece of art, the tone, facial expression, and body language were imperative. In this live performance along with linguistic factors, several paralinguistic features operated side by side: "Facial expressions, dress, and gestures take their place along with architecture and sets to convey cultural information that is both verisimilar and an index of the ideologies, values, and conventions by which we order experience and predicate activity" (Klein, 1981).

The inner feelings of the central characters such as Raees and Begum Raees were portrayed through body gestures as they became more and more hallucinated under great stress of their guilt. In Raees, Begam Raees showed her guilt and madness by using body language, tone, pitch, and facial gestures which helped her depict the inner emotional state and motives of the character. The dialogue delivery, facial expressions, and voice qualities of all the other performers such as Dilawar, Jadogarnia'n, Murad and Jaffar, etc. performing in this play were laudable. The Jadogarnia'n also created comedy along with their witty evil and malevolence, which was not present in the source text. They deployed different paralinguistic elements with the help of costumes and makeup of the witches which created an atmosphere that was simultaneously playful, gloomy, and scary. Moreover, the stage was symbolic as well since it remained dark and gloomy. The director used different types of lights to impact the characters' body language and facial expressions as well as to depict different events and scenes. He used wings in lights, shadow lights, profile lights to focus the characters and to create an image of background scenes on the stage. He also used

Shafiq, S., \& Anwar, N. (2020). Raees as Macbeth-A transcultural adaptation. International Journal of Linguistics, Literature and Culture, 6(4), 6-15. https://doi.org/10.21744/ijllc.v6n4.901 
flickering of red light to show war scenes and bloodshed and a fog machine to depict day and night. These prompts had a substantial impact on the audience and they became involved in the story.

Title-Macbeth to Raees

Translation of the title is a very important decision an adapter has to take during the adaptation process. Mehmood domesticates the title of the play title so that the potential audience or readers familiarize themselves with the play. Through the title Raees, he points out the significance of the protagonist, foreshadowing the story of a royal official, politics, and conspiracies in the royal palaces and recreates on stage the tableau vivant of royal aristocracies. As Shakespearean plays are for all contexts and settings, the translator wants it to be more pertinent for the Pakistani audience. Pakistani audience like plays with royal fantasies and about the narratives of ambitious rulers and warriors. They like to watch plays about Mughal, Turkish royal dynasties, and the plays on Muslim brave warriors and leaders like Dirilis Ertugrul, Kurulus Ottoman, Sultan Abdul Hamid, Tipu Sultan, Mohammad bin Qasim, etc. They are attracted by such titles and narratives. Another motive behind the selection of this title is Muslims' affiliation with the Muslim brave leaders and warriors. In Turkish and Arabic, the word Reis is used as a title for the rulers (Wiktionary: 21 Mar 2019). Raees/ Reis also served as a Turkish military rank during the great Ottoman Empire. This rank is parallel to that of Admiral Commander-in-chief of the Ottoman Army fleet. As Macbeth is a Royal general in Shakespeare's play so to alter it in the local context, the scriptwriter gives it a parallel title.

\section{Indigenization - Characters' Names}

Table 1 shows the list of characters who are present in the adapted text but with local names. This conversion of names helped the local performers to get the true essence of the character they are performing. Additionally, this conversion of names also helped the audience/readers to get the true essence of the play in their native language and enjoy the emotions and feelings of the Shakespearean tragedy. In table 1, I have described the character description in the source and adapted text. The character's role and status are almost the same in both texts but they are altered in the milieu of names and locales. Table 2 illustrates the names of the characters which the translator has eliminated from the adapted version. The translator has to reduce and compress the script of the source text for stage performance so he has eliminated and merged some characters. This table lists the character's name, its portrayal in the source text, the reference of the act, and the scene in which they appear in the source text and the roles which are altered in the adapted text. Apparition 1, Apparition 2, and Apparition 3 in Act 4 Scene 1 are altered in the characters of Weird sisters (three witches) in Raees. But the minor characters of an old man in Act 2 Scene 4, Menteith in Act 5 Scene 3, and the Murderer 3 in Act 3 Scene 3 are eliminated in the adapted version of Macbeth. Table 3 is the list of characters, who are physically not a part of the play but they are mentioned as absent characters in the play. In Raees, the translator has shifted the context of the Scottish-Norwegian War with the Greco-Persian War. He has altered the Irish-Norwegian alliances against Scotland with the Greeks against the Persian Empire. In Act 1 Scene 2, the translator merges the characters of Macdonwald an Irish King, Sweno the Norwegian King with a single character as Shah-e-Yunan (the only foe of Persia).

Table 1

List of characters in Macbeth and Raees

\begin{tabular}{llll}
\hline Source Text & Adaptation & Character Description & Character Description \\
\hline Macbeth & Raees & King of Scotland & Ameer-e-Karad \\
Lady Macbeth & Zamurad & Macbeth's wife & Raees Ki Begum \\
Witch 1 & Jadogarni 1 & Evil spirits & Jadogarni 1 \\
Witch 2 & Jadogarni 2 & Evil spirits & Jadogarni 2 \\
Witch 3 & Jadogarni 3 & Evil spirits & Jadogarni 3 \\
Hecate & Malika Jadogarni & Queen of the witches & Malika Jadogarni \\
Banquo & Dilawar & a general & Shahi Fouj ka general \\
King Duncan & Shah-e-Faras & King of Scotland & Badshah \\
Macduff & Mushtaq & Scottish Royal official & Ameer-e-Khas \\
Malcolm & Murad & Duncan's elder son & Badshah ka Beta \\
Donalbain & Dadoo & Duncan's younger son & Badshah ka beta \\
Fleance & Taimoor & Banquo's son & Dilawar ka Beta \\
\hline
\end{tabular}




\begin{tabular}{llll}
\hline \hline Lennox & Sadiq & Scottish Royal official & Ameer \\
Ross & Jaffar & Scottish Royal official & Ameer \\
Murderer 1 & Jilad 1 & employed by Macbeth & Jilad 1 \\
Murderer 2 & Jilad 2 & employed by Macbeth & Jilad 2 \\
Porter & Pehradar & Gatekeeper & Pehradar \\
Lady Macduff & Begum Mushtaq & Macduff's wife & Begum Mushtaq \\
Gentlewoman & Khadima & Caretaker & Zamurd ki Khadima \\
Angus & Nizaam & Scottish Royal official & Ameer \\
Caithness & Taooos & Scottish Royal official & Ameer \\
Siward & Siward & An English General & Shah-e-Yunan \\
Young Siward & Nujawan Siward & Siward's son & Siward ka Beta \\
Seyton & Saleem & Macbeth's armorer & Raees ka afsar \\
Boy & Naeem & Macduff's son & Mushtaq ka beta \\
Doctor & Hakeem & Lady Macbeth's doctor & Hakeem \\
Captain & Sipahi & Captain & Sipahi \\
Ghost & Rooh & Macbeth hallucination & Dilawar ki Rooh \\
\hline
\end{tabular}

Table 2

Characters eliminated in adapted text

\begin{tabular}{llll}
\hline Character & Description & Reference & Replacement \\
\hline Apparition 1 & A Head With Armor & Act 4 Scene 1 & Witch (weird sisters) \\
Apparition 2 & A Bloody Child & Act 4 Scene 1 & Witch (weird sisters) \\
Apparition 3 & A Crown Child & Act 4 Scene 1 & Witch (weird sisters) \\
Old man & Minor Character & Act 2 Scene 4 & Eliminated \\
Mentheith & Royal Official & Act 5 Scene 3 & Eliminated \\
Murderer 3 & Hired by Macbeth & Act 3 Scene 3 & Eliminated \\
\hline
\end{tabular}

Table 3

Abstract characters

\begin{tabular}{lll}
\hline Source Text & Adapted Text & Reference \\
\hline Macdonwald (Irish King) & Shah-e-Yunan (one character) & Act 1 Scene 2 \\
Sweno (Norwegian King) & Shah-e-Yunan (one character) & Act 1 Scene 2 \\
Thane Of Cowdar & Sipah-e-Salar & Act 1 Scene 2 \\
English Court (King Edward) & Shah-e-Misar & Act 3 Scene 6 \\
\hline
\end{tabular}

\section{Adjustment-Historical Context}

The translator has altered the historical setting of the source text. This alteration leads to historical changes in the adapted text Raees. Shakespeare sets the play in Scotland, during medieval times and he uses the historical background of Scottish-Norwegian War, which was fought in 1262-1266 between Scotland and the Kingdom of Norway and its allies, Kingdom of the Isles and Orkney. This war concluded in Scottish victory through the Treaty of Perth with Scottish control over the Hebrides and Isle and Norwegian dominion over Shetland and Orkney. ${ }^{\mathrm{c}}$ Mehmood has altered the historical context of Scottish-Norwegian War with the Greco-Persian Wars between Greece and the Persian States which started in 492 BC and lasted until 449 BC. Darius the Great was the fourth monarch of the Persian Achaemenid Empire. He ruled over the area of western India to Eastern Europe. In 513 BC Darius occupied Thrace and Macedonia. In 546 the Persian Empire succeeded Ionian Greeks after the defeat of Asia Minor while the other part of Greece was freed. Persian government deputed tyrant governors in most of the Ionian

${ }^{\mathrm{c}}$ https://www.britannica.com/topic/Wars-of-Independence-Scottish-history 
cities. In 449 BC, the Peace of Callias finally helped to eradicate the conflicts between Greece and Persia. Although the translator tries to retain the plot of the source text his vigilant alteration has changed the whole scenario of the context, characters, historical background of the adapted version of Macbeth. ${ }^{\mathrm{d}}$

Locale - A Transcultural Shift

Besides, the changes made in the historical context the milieu of the adapted text are also altered by the translator. The setting of Macbeth is in Scotland of Medieval times. The translator has changed the locale to the South Asian setting. The given table illustrates this change.

Table 4

Shift in setting

\begin{tabular}{ll}
\hline Locale in Macbeth & Locale in Raees \\
\hline Scotland & Faras (Persia) \\
Norway & Yunan (Greece) \\
Fife & Sham (Syria) \\
Forres & Sikandria \\
England & Yemen \\
Ireland & Konya \\
Fife & Kharad \\
River Hell & Darya e Qarn \\
England & Misar (Egypt) \\
Dunsnane & Khird \\
\hline
\end{tabular}

\section{Conclusion}

By using Hutcheon's adaptation theory, this research has explored the transcultural variation employed by the Government College University Dramatic Club (GCUDC), Lahore. Shakespeare's plays are a great choice for adaptation across cultures because his plays provide the audience of different age groups, various cultures with ideal material, familiarity, and exciting scenes. Although there were many limitations of budget, cultural and social convictions, and resources, as shared by the organizers, the play was wonderfully adapted by the GCUDC team. Unfortunately, they do not have any video of the play. So for this research, I had to rely on the script, interviews, and responses of the director, producers, and the available performers. I have collected data from source texts, scripts, articles, interviews, observations, questionnaires, and group discussions to explain the cultural impact of Shakespeare's adaptation. The present research strongly suggests that although the status of adaptation in Pakistani educational context is not on a par with the western countries, with time, it is hoped that more advancement in this field will be observed.

\section{Conflict of interest statement}

The authors declared that they have no competing interests.

\section{Statement of authorship}

The authors have a responsibility for the conception and design of the study. The authors have approved the final article.

\section{Acknowledgments}

We are grateful to two anonymous reviewers for their valuable comments on the earlier version of this paper.

\footnotetext{
${ }^{\mathrm{d}}$ https://www.britannica.com/event/Greco-Persian-Wars. Accessed 25 Jan 2019
} 


\section{References}

Benjamin, W., Zohn, H., \& Arendt, H. (2019). Illuminations: essays and reflections. Boston; New York: Mariner Books, Houghton Mifflin Harcourt.

Bruhn, J. (2013). Adaptation studies: New challenges, new directions. A\&C Black.

Cuddy-Keane, M. (2003). Virginia Woolf, the Intellectual, and the Public Sphere. Cambridge University Press.

Desmet, C., \& Sawyer, R. (2013). Shakespeare and Appropriation. London: Taylor and Francis. http://doi.org/10.1057/9781137375568

Egan, R. G. (1993). The Appropriation of Shakespeare: Post-Renaissance Reconstructions of the Works and the Myth. Edited by Jean I. Marsden. New York: St. Martin's Press, 1991. Pp. 222+ illus. \$39.95. Theatre Research International, 18(2), 143-144. https://doi.org/10.1017/S0307883300017302

Ellis, J. (1982). The literary adaptation. Screen, 23(1), 3-5.

Fortier, D. F. M. (2000). Adaptations of Shakespeare: A Critical Anthology of Plays from the Seventeenth Century to the Present. Psychology Press.

GCU Stages Urdu Adaptation of Shakespeare's Macbeth. (2016, May 31). Daily Times. Retrieved from https://dailytimes.com.pk/79026/gcu-stages-urdu-adaptation-of-shakespearesmacbeth/

Grazia, M. D., \& Wells, S. W. (2010). The new Cambridge companion to Shakespeare. New York: Cambridge University Press.

Hutcheon, L. (2006). Beginning to theorize adaptation. A theory of adaptation, 1-32.

Hutcheon, L., \& O'Flynn, S. (2013). Theory of Adaptation. Routledge.

Klein, M., \& Parker, G. (1981). The English novel and the movies. Frederick Ungar.

Marsden, J. I. (1991). The Appropriation of Shakespeare: Post-Renaissance reconstructions of the works and the myth. Wheatsheaf Books.

Wells, S., Stanton, S., \& Stanley, W. (Eds.). (2002). The Cambridge companion to Shakespeare on stage. Cambridge University Press. 